\title{
Редкие и исчезающие виды животных в таксидермической коллекции Национального музея Тувы
}

\author{
Чайзу С. Кыргыс, Валерия Ч. Донгак
}

Национальный музей им. Алдан-Маадыр Республики Тыва, Российская Федерация

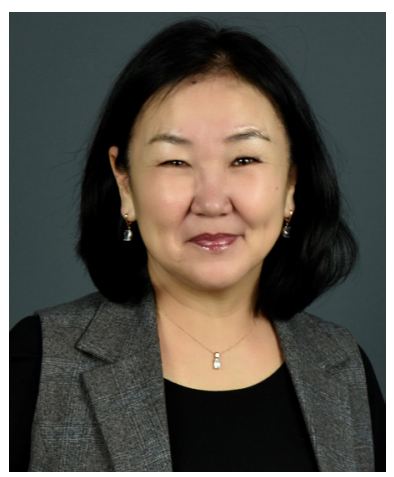

Национальный музей Тувы является не только культурным, но и эколого-просветительским центром региона. В статье анализируется экологическое состояние фауны млекопитающих Тувы на примере редких и исчезающих видов животных в зоологической коллекциии Национального музея Тувы и обозначается роль музея как «банка данных» ценного биологического материала в Алтае-Саянском экорегионе.

Основу естественнонаучного фонда музея составляет таксидермическая коллекция. Она состоит из 790 единиц чучел и тушек животных. Среди экспонатов 59 редких и исчезающих видов животных особую ценность представляют виды, имеющие международный статус охраны - снежный барс (Uncia ипсіа), архар (алтайский горный баран) (Ovis aттоп), дзерен (Procapra gutturosa).

Проводимая в течение длительного времени научно-хранительская деятельность музея позволяет обеспечивать непрерывность исследований флоры и фауны региона. Анализ имеющегося фондового таксидермического материала показывает, что в настоящий момент целенаправленного пополнения зоологических коллекций музея не требуется. Однако необходимо наладить работу по научной инвентаризации объектов, обеспечивать непрерывное накопление данных по отдельному виду охраняемой фауны. Такой подход позволит систематизировать научное направление работы естественнонаучного блока музея.

Принимая за основу системное изучение фондовых материалов музея, авторы ставят вопрос о необходимости мониторинга исчезающих и редких видов животных в республике.

Ключевые слова: Национальный музей Тувы; зоологическая коллекция; Красная книга; биоразнообразие; Алтае-Саянский экорегион; Международный союз охраны природы; проблемы экологии; экологическая культура

\section{Для цитирования:}

Кыргыс Ч. С., Донгак В. Ч. Редкие и исчезающие виды животных в таксидермической коллекции Национального музея Тувы [Электронный ресурс] // Новые исследования Тувы. 2019, № 2. URL: https://nit.tuva.asia/nit/article/ view/855 (дата обращения: дд.мм.гг.). DOI: 10.25178/nit.2019.2.15

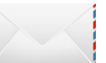

Кыргыс Чайзу Суван-ооловна - кандидат биологических наук, старший научный сотрудник отдела краеведения и туризма Национального музея им. Алдан-Маадыр Республики Тыва. Адрес: 667000, Россия, г. Кызыл, ул. Титова, д. 30. Тел. +7 (394-22) 2-28-04. Эл. адрес: chaizu@rambler.ru ORCID ID: 0000-0001-6347-5896

Донгак Валерия Чаш-ооловна - старший научный сотрудник, отдел краеведения и туризма Национального музея им. АлданМаадыр Республики Тыва. Адрес: 667000, Россия, г. Кызыл, ул. Титова 30. Тел.: +7 (39422) 2-28-04. Эл. адрес: dongak-1964@ mail.ru ORCID ID: 0000-0001-8249-5980

Kyrgys Chaizu Suvan-oolovna, Candidate of Biology, Senior research fellow, Department of Local History and Tourism, AldanMaadyr National Museum of the Republic of Tuva. Postal address: 30 Titov St., 667000 Kyzyl, Russian Federation. Tel.: +7 (39422) 2-28-04. E-mail: chaizu@rambler.ru

Dongak Valeriya Chash-oolovna, Senior research fellow, Department of Local History and Tourism, Aldan-Maadyr National Museum of Tyva. Postal address: 30 Titov St., 667000 Kyzyl, Russian Federation. Tel.: +7 (39422) 2-28-04. E-mail: dongak-1964@mail.ru 


\title{
Rare and endangered species in the taxidermy collection of the National Museum of the Republic of Tuva
}

\author{
Chaizu S. Kyrgys, Valeriya Ch. Dongak \\ Aldan-Maadyr National Museum of the Republic of Tuva, Russian Federation
}

\begin{abstract}
The Aldan-Maadyr National Museum of the Republic of Tuva is both a cultural and environmental center of the region. This article assesses the environmental status of species of mammals found in Tuva. paying particular attention to rare species of animals listed in the Red Data Books of the Russian Federation and the Republic of Tuva, their protected status, and categories of endangerment. The article underscores the importance of the zoological collection of the National Museum of the Republic of Tuva as a "databank" of valuable biological material of the Altai-Sayan ecoregion.

The basis of the museum's natural science fund is the taxidermy collection, which consists of 790 items. Among the exhibits are 59 rare and endangered species. Of particular value are those with international protected status, including the snow leopard (Uncia uncia), argali (Ovis ammon), and Mongolian gazelle (Procapra gutturosa).

The museum's long history of scientific work and ongoing conservation activities help ensure continuity of research on flora and fauna of the region. The analysis of the museum's taxidermy collection allows the authors to assert that, at the moment, there is no need for purposeful replenishment of the museum's zoological collections. However, it is necessary to set up a research program to study the museum's existing scientific inventory of objects and to develop a system for the regular accumulation and updating of data on particular types of protected fauna. Such an approach will facilitate systematization of the scientific work of the museum's local history department and allow museum personnel to participate in regional biodiversity monitoring programs.

Accepting the systemic study of the collection as the methodological basis, the authors conclude by calling for a monitoring procedure to protect the rare and endangered species of animals in Tuva.
\end{abstract}

Keywords: National Museum of the Republic of Tuva; zoological collection; Red Data Book; biodiversity; Altai-Sayan ecoregion; International Union for the Conservation of Nature (IUCN); environmental issues; emvironmental culture

\footnotetext{
For citaton:
Kyrgys Ch. S. and Dongak V. Ch. Rare and endangered species in the taxidermy collection of the National Museum of
the Republic of Tuva. The New Research of Tuva. 2019, № 2 [online] Available at: https://nit.tuva.asia/nit/article/view/855
(access date ...). DOI: 10.25178/nit.2019.2.15
}

\section{Введение}

Национальный музей им. Алдан-Маадыр Республики Тыва, отмечающий в этом году 90-летие, является культурным, научным и эколого-просветительским центром, позволяющим посетителям ознакомиться не только с культурой населения, но и с богатством природных ресурсов и разнообразием флоры и фауны Тувы. В зоологической коллекции музея есть экспонаты, которые вошли в 1950-1960-х гг. как обычные охотхозяйственные виды, но со временем они изменили свой статус - стали считаться исчезнувшими, исчезающими или редкими видами животных. Этот факт наглядно свидетельствует об угрозах сохранения биоразнообразия региона и о том, какую важную миссию выполняет также главный музей республики. Именно музей, имеющий значительный естественнонаучный фонд, может выступать как учреждение, сохраняющее преемственность и непрерывность между прежними и современными исследованиями флоры и фауны региона.

Целью данной работы является анализ экологического состояния фауны млекопитающих Тувы на примере редких и исчезающих видов животных в зоологической коллекции Национального музея Тувы и обозначение роли музея как «банка данных» ценного биологического материала в Алтае-Саянском экорегионе. Источниковой базой выступили экспозиционный материал, музейная фондовая документация (книга поступления предметов, инвентарные книги, картотека, тематико-структурный план экспозиций, топографические описи, акты выдачи). 


\section{О коллекции редких и исчезающих животных музея}

Создание и становление Национального музея Тувы пришлись на период формирования всех социальных сфер молодого государства - Тувинской Народной Республики (ТНР). Учрежденный правительством, музей имел статус государственного и на него возлагалась важнейшая культурно-образовательная задача (Дыртык-оол, 2005).

В структуре музея молодого тувинского государства отдел природы появился в 1941 г. При содействии Всероссийского общества по культурным связям с зарубежными странами (ВОКС) для установления связи с научными учреждениями и музеями в 1929 г. в Советский Союз был направлен первый директор музея В. П. Ермолаев. Из Москвы и Ленинграда им были привезены школьные пособия (карты, мокрые препараты земноводных, пресмыкающихся и др.), чучела обезьян и птиц, ставшие первыми экспонатами отдела природы. Некоторые экспонаты для отдела природы были изготовлены в СССР по заказу через ВОКС по темам «Происхождение жизни», «Происхождение человека» и «Учение дарвинизма» (там же).

Весной 1942 г. Государственному музею ТНР имени Алдан-Маадыр было предоставлено здание бывшего клуба профсоюзов имени Оюна Шагдыр-Сюрюна. И отдел природы был одним из трех отделов музея, который получил активное развитие под заведованием В. П. Ермолаева в 1951-1953 гг. И до настоящего времени в архиве музея хранятся разработанные им материалы: тематико-экспозиционные планы, тексты экскурсий по разделам отдела природы. Экспозиция отдела природы занимала два зала, где были представлены в основном фотоматериалы о богатстве и разнообразии природы Тувы, отснятые самим В. П. Ермолаевым. В качестве дополнительных материалов в экспозициях использовались таблицы, схемы, карты и другие привезенные учебные материалы из Москвы. По отчетам В. П. Ермолаева следует, что он всегда работал с членами музейного совета, которые помогали ему создавать экспозицию, собирать шкуры промысловых зверей, случайные палеонтологические находки (бивни и зубы мамонта, рога тура, череп носорога, бизона и др.). Данные сведения отражены в Книгах поступлений предметов, хранящихся в фондах Национального музея Республики Тыва (КП 1/1-1975), комплектование которых происходило за счет закупа музеем, даров, покупок и обмена предметов.

Через экспозицию отдела природы в музее посетители могли знакомиться с географической характеристикой, геологией и геоморфологией, климатом, растительным и животным миром Тувы. Почти каждый, кто посещал музей до переезда его в новое здание в 2008 г. по ул. Титова, д. 30, помнит, как красочно и содержательно были показаны в старом здании по адресу ул. Ленина, д. 7 натурные экспонаты и образцы, раскрывающие основу ландшафтов: «Тайга», «Горы», «Степь», «Водные угодья» (следует подчеркнуть, что и в новом здании оформление экспозиций выдержано почти без изменений - согласно ландшафтному принципу). Также многим запомнился оформленный В. П. Ермолаевым раздел «Палеонтология», который был представлен в прежнем здании музея по геохронологической шкале показом трех основных периодов разных геологических периодов: каменноугольного, юрского и четвертичного.

В настоящее время экспозицией (расположенной в залах на втором этаже № 1 «Тува - жемчужина в центре Азии», № 2 «Степные экосистемы» и № 7 «Тайга») о природных богатствах Тувы начинается знакомство не только с музеем, но и с Тувой; показано разнообразие ландшафтов, животного и растительного мира республики. Сформированные по ландшафтному принципу, диорамы воссоздают весь спектр природных экосистем Тувы, с присущим только им растительным и животным миром, дополненные художественным оформлением конкретного природного комплекса. Соответственно, на каждом «куске», представляющем какую-либо природную зону, на обозрение выставлены наиболее яркие представители фауны и флоры Тувы.

В зоологической коллекции музея особое место занимают редкие и исчезающие виды животных, занесенные в Красный список Международного союза охраны природы (МСОП), в Красную книгу Российской Федерации и Красную книгу Республики Тыва. Например, это снежный барс (Uncia uncia), apхар (алтайский горный баран) (Ovis ammon), дзерен (Procapra gutturosa).

Среди всех естественнонаучных сборов музея коллекция по фауне является самой многочисленной. Заметное место в ней занимает коллекция млекопитающих, насчитывающая 1102 единиц. Примечательно, что в начале формирования фаунистической коллекции музея в 1950-1960 гг. все объекты животного мира при сборах классифицировались как обычные охотхозяйственные виды. Статус и категории редкости видов были определены после выхода «Красной книги СССР» (Красная книга СССР, 1978).

Целевое направление и комплектование фондов имело высокий уровень в период с 1963 по 1977 гг., когда в музее была штатная единица таксидермиста. Существенные пополнения коллекции, напри- 
мер, чучел крупных животных произошли в результате многочисленных экспедиций и полевых работ Ивана Матвеевича Путинцева, известного таксидермиста и большого знатока животного мира Тувы.

Проведенный нами анализ сведений о пополнениях фондов показал, что комплектование таксидермической коллекции имеет тенденцию снижения с конца 1990-х гг. и прекратилось с 2011 г. (диаграмма 1). Произошедший кризис объясняется отсутствием профессионалов-таксидермистов в штате музея (а в республике - всего 2 специалиста). В связи с этим назрел вопрос об обучении собственных кадров и оборудовании специального помещения для таксидермических работ.

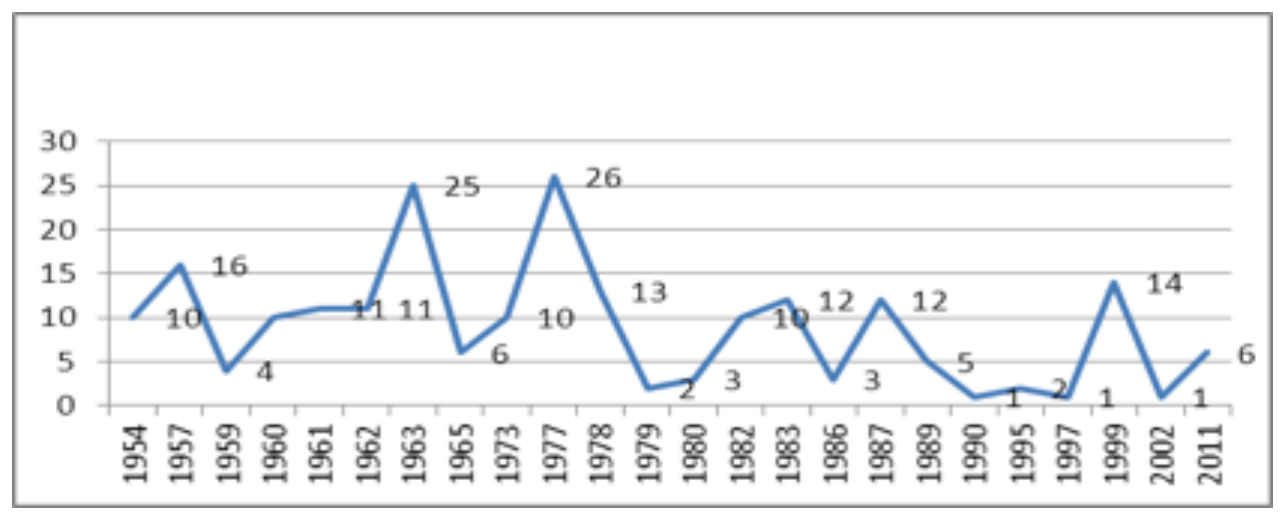

Диаграмма 1. Комплектование фонда в разные годы. Diagram 1. Taxidermic collection, acquisition over years.

\section{Краснокнижные животные в коллекции}

Красная книга - юридическая основа сохранения редких видов. С середины XX в. исследования по инвентаризации редких видов привели к принятию необходимых мер по их охране на глобальном уровне. С момента публикации первой Красной книги МСОП в 1963 г. стали появляться национальные и региональные Красные книги, на основании которых принимаются меры по сохранению уязвимых видов. Для включения в Красную книгу классификация животных по редкости их таксонов и популяций осуществляется по 6 категориям: вероятно исчезнувшие (0), находящиеся под угрозой исчезновения (1), сокращающиеся в численности (2), редкие (3), неопределенные по статусу (4) и восстановленные и восстанавливающиеся (5) (Ильяшенко В., Ильяшенко Е., 2000).

В Туве первая Красная книга появилась почти двадцать лет назад в двух частях: (том «Растения») (Красная книга Республики Тыва: Растения, 2002) и (том «Животные») (Красная книга Республики Тыва: Животные, 2002). Следует подчеркнуть, что издание было проиллюстрировано снимками, а также рисунками, выполненными по чучелам и тушкам редких видов животных зоологической коллекции музея. Составители в основном ссылались на трудности фотографирования животных в естественной среде, и наличие чучел исключительно редких представителей фауны в коллекциях музея сыграло важную роль в наглядном представлении животных Красной книги Тувы.

Одновременно с тем, что занесенные в Красные книги разного уровня редкие и исчезающие объекты фауны представлены в коллекциях музея и несут историческую, научную и природоохранную ценность, они также имеют многостороннее значение для сохранения традиций и жизнедеятельности тувинского народа. Несомненно, когда многие животные, например, сурок тарбаган - редкий в масштабе страны и требующий охраны вид - является традиционным объектом добычи и рациона жителей высокогорных районов Тувы, создается противоречивая ситуация между соблюдением природоохранного законодательства и сохранением традиций. Если традиции яркого вида охоты на тарбагана, со своеобразным ритуалом (обрядом переодевания, элементами танцев при подходе к животному и т. д.), почти утеряны и не практикуются, то в рационе жителей суровых гор сурчатина сохраняется, то есть ведется скрытая, а значит, незаконная добыча. И здесь, в отличие от надзорных структур, принимающих жесткие меры наказания (в виде штрафов, изъятия орудий добычи, возбуждения административных или уголовных дел), музею отводится важная роль в освещении вопросов сохранения редких видов, доведении информации до каждого посетителя посредством демонстрации уникальности и уязвимости того или иного объекта флоры и фауны. 
Ниже приводятся описания некоторых редких видов зоологической коллекции музея, где наряду со стандартными научными сведениями об экспонатах затронуты вопросы их экологического благополучия в регионе.

\section{Монгольский дзерен (Procapra gutturosa Pallas, 1777¹).}

Несмотря на то, что в предыдущей версии Красной книги Республики Тыва (Красная книга ..., 2002), виду придавался статус находящегося под угрозой исчезновения, в новой версии (Красная книга ... , 2018), дзерена исключили из перечня представителей фауны Тувы. В Красной книге Российской Федерации вид имеет категорию 1 и статус находящегося под угрозой исчезновения. Таким образом, его исключение из региональной Красной книги, по нашему мнению, приводит к правовой коллизии. Данное утверждение связано с тем, что обязательным условием при создании региональных Красных книг является включение в них животных, занесенных в Красную книгу Российской Федерации, в свою очередь, руководствующейся списком МСОП.

Дзерен (по-тувински чээрен) относится к отряду парнокопытных (Artiodactyta), семейству полорогих (Bovidae). Зобатая антилопа (другое название дзерена) была распространена на юге Тувы, совершала заходы в Тувинскую котловину через хребет Восточный Танну-Ола. По сведениям М. Н. Смирнова, извест-

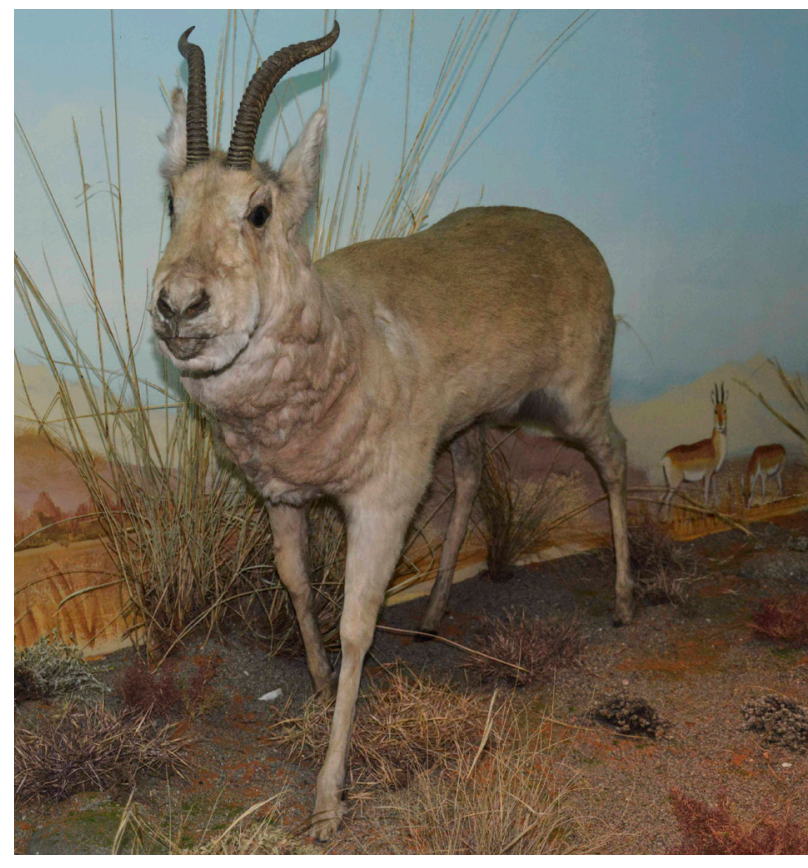

Фото 1. Дзерен в диораме «Степные экосистемы». Фото А. Д. Куулар, 2019 г.

Photo 1. The dzeren (Mongolian gazelle) in the «Ecosystems of the steppes» dioram. Photo by A. D. Kuular, 2019. ного исследователя промысловых млекопитающих Южной Сибири, численность дзерена в Туве в конце 1950-х гг. оценивалась в 5000 особей (Смирнов, 2002а: 145). Затем произошло катастрофическое снижение из-за антропогенного пресса: браконьерства, распашки целинных земель - их местообитаний. Последние сведения о встречах дзеренов в Туве получены в конце 1970-х гг., а заходы мелких групп или единичных особей из Монголии наблюдаются в сухих степях по бассейну р. Тес-Хем.

В 1961 г. в России охота на дзерена была полностью запрещена. Однако в соседней Монголии дзерен остается охотничьим видом, по категории МСОП имеет статус вида с низким риском для исчезновения. В связи с тем, что забайкальская популяция с конца 1990-х гг. начала восстанавливаться и охраняться в пределах Даурского заповедника, появились шансы реинтродукции и восстановления вида в пределах исторического ареала в южных районах Тувы, а в рамках природоохранной стратегии сохранения вида разработана программа восстановления популяции дзерена (Кирилюк, Лущекина, 2017). В настоящее время приграничные с Северо-Западной Монголией типичные биотопы ${ }^{2}$ зобастой антилопы не подвергаются распашкам, считаются восстановленными. Продуктивность данных сухих степей составляет в среднем 2 тонны на гектар 3 , что является показателем устойчивости стабильных пастбищ (Титлянова и др., 2002: 122, 127), которые могут прокормить как домашний скот, так и диких копытных.

По данным МСОП, группой исследователей по антилопам было предложено выделить два подвида дзерена: монгольский дзерен (номинативный подвид) и алтайский дзерен (Procapra gutturosa altaica). Второй подвид имеет несколько более темную шерсть, более широкий череп, более крупные коренные зубы и более широко расставленные рога (Сорокин, 2005). Ввиду незначительных морфологических отличий от номинативного версия выделения второго подвида дзерена не получило развития. Тем не менее, исследования вида продолжаются, и учеными предлагается для изучения, например, филогеографии ${ }^{4}$, использовать ткани различной степени сохранности, включая музейные образцы.

${ }^{1}$ Здесь и далее, согласно правил биологической номенклатуры, полное научное название вида на латыни включает также имя ученого, давшего это название, и год описания.

${ }^{2}$ Биотоп - однородный по условиям жизни для определенных видов растений или животных участок территории.

${ }^{3}$ Масса производимого растительного вещества в тоннах на площади в один гектар.

${ }^{4}$ Область исследований, связанная с принципами и процессами, ответственными за географическое распространение генных родословных. 
Чучело дзерена (фото 1), выставленное в экспозиции «Степные экосистемы», было изготовлено таксидермистом И. М. Путинцевым по заказу музея в 1958 г. За 60-летний срок экспонирования состояние и сохранность экземпляра остается на хорошем уровне.

Алтайский горный баран (Ovis ammon ammon Linnaeus, 1758).

Категория и статус: 1 - находящийся под угрозой исчезновения вид.

Архар (по-тувински аргар - самка, кошкар - самец горного барана) относится к отряду парнокопытных (Artiodactyta), семейству полорогих (Bovidae). В коллекции музея архар представлен чучелами двух взрослых особей и ягненка, изготовленными таксидермистом И. М. Путинцевым в 1960 г. (фото 2). В настоящее время состояние чучел не вызывает беспокойства. Экспонаты представлены в экспозиции «Высокогорные экосистемы».

Самые крупные из представителей горных баранов, архары когда-то были распространены повсеместно по низкогорьям Тувы. Сегодня ареал значительно сузился до труднодоступных горных мест на юго-западе Тувы на границе с Республикой Алтай и Монголией. Вид взят под охрану заповедником «Убсунурская котловина», однако его ареал выходит за пределы границ охраняемой территории. В соседней Монголии архар остается охотничьим, трофейным видом.

В Туве существует традиционное ремесло - изготовление предметов искусства из рогов архара. Нередки

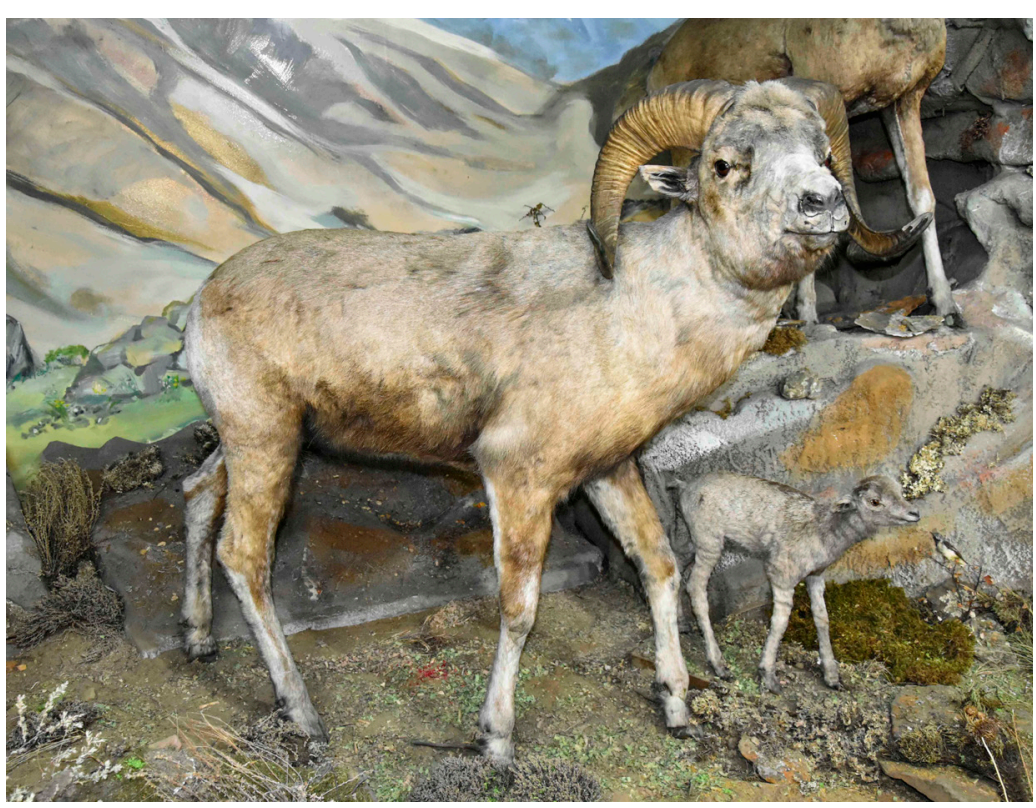

Фото 2. Архары в экспозиции «Высокогорные экосистемы». Фото А. Д. Куулар, 2019 г.

Photo 2. Argalis in the «Ecosystems of the highlands» exposition. Photo by A. D. Kuular, 2019. случаи нахождения местными жителя-

ми останков животных. Черепа и рога в последующем становятся предметом скупки на теневом рынке. Сегодня данная деятельность подпадает под действие статьи Уголовного кодекса Российской Федерации 258.1. «Незаконная добыча и оборот особо ценных диких животных и водных биологических ресурсов, принадлежащих видам, занесенным в Красную книгу Российской Федерации и (или) охраняемым международными договорами Российской Федерации». В этой связи, в первую очередь, природоохранным ведомствам необходимо на регулярной основе проводить разъяснительную работу среди населения, а также наладить оказание юридической и иной помощи ремесленникам, занятым народными промыслами, во избежание проблем с законодательством.

Лесной северный олень (Rangifer tarandus sibiricus Murray, 1866).

Категория и статус: 3 - редкий узкоареальный подвид.

В настоящее время основные ресурсы вида сосредоточены в высокогорьях Большого Саяна в Тоджинском районе, на востоке Каа-Хемского и Тере-Хольского районов. Очаговый ареал приходится на хребет Обручева, нагорье Сангилен, на западе - в северной части Шапшальского хребта. Специальные учетные работы по определению ресурсов лесного северного оленя в республике не проводились. Ориентировочная численность в 1990-е гг. оценивалась от 1200 до 1500 особей (Смирнов, 2002b: 144). По данным зимних маршрутных учетов Государственного комитета по охране объектов животного мира и биологических ресурсов Республики Тыва, с которыми один из соавторов данной статьи регулярно работает, в Тоджинском и Тере-Хольском районах в 2011-2012 гг. численность лесного северного оленя ориентировочно оценивалась в 4-4,5 тыс. особей.

В перспективе, в связи с гораздо меньшим уровнем освоения угодий оленеводами, охотниками, возможен дальнейший рост численности диких северных оленей. В постсоветский период, в результате развала совхозов и других хозяйств, были факты перехода многих домашних оленей в стада диких сородичей, что способствовало увеличению численности последних. Также, по утверждениям оленеводов Тоджи, часты случаи угона домашних оленей дикими (Donahoe, 2004: 111). 


\section{НОВЫЕ ИССЛЕДОВАНИЯ ТУВЫ}

www.nit.tuva.asia

№2

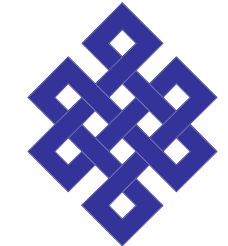

\section{THE NEW RESEARCH OF TUVA}

Отсюда следует, что как биологический вид объект - очень гибкий, в то же время его кормовая база (ягельные пастбища) легко уязвима, в связи с чем требуется охрана местообитаний от воздействия негативного характера (пожары, лесозаготовка, строительство дорог).

Одомашненный сородич лесного подвида северного оленя традиционно использовался тувинцами-тоджинцами, признанными коренным малочисленным народом Севера, Сибири и Дальнего Востока Российской Федерации, как вьючный транспорт, также удобный для верховой езды в таежных условиях (фото 3). С северным оленем тесно связана жизнь тувинцев-тоджинцев, их этническая идентичность определяется его наличием, как сами оленеводы

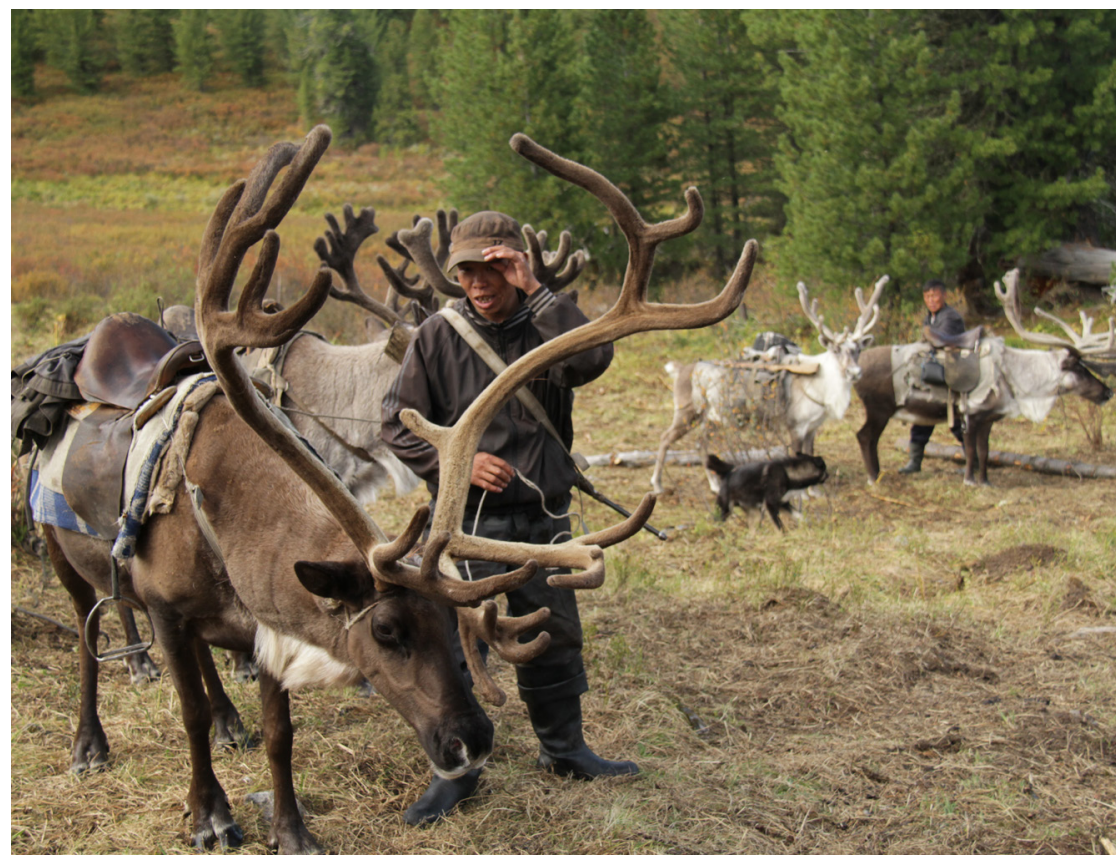

Фото 3. Северный олень - незаменимый таежный транспорт. Фото Б. Донахо, 2011 г.

Photo 3. The reindeer are the indispensable means of transport in the taiga. Photo by B. Donakho, 2011. признаются: «Без оленей мы не тожу кижи (тувинцы-тоджинцы)» (Donahoe, 2004: 135).

В коллекции музея имеется чучело домашнего лесного северного оленя, экспонат представлен в диораме «Тоджинский чум».

Ирбис (снежный барс) (Uncia uncia Schreber, 1776).

Категория и статус: 1 - находящийся под угрозой исчезновения вид.

Ирбис (по-тувински ирбиш) относится к отряду хищных (Carnivora), семейству кошачьих (Felidae), внесен в Приложение 1 Конвенции о международной торговле видами дикой фауны и флоры, находящимися под угрозой исчезновения (СИТЕС; Конвенция о международной торговле ..., Электр. ресурс).

По сведениям исследователя ирбиса в Туве А. Н. Куксина, за период после выхода первого издания Красной книги Республики Тыва благодаря проекту Всемирного фонда дикой природы (WWF) «Oбе-

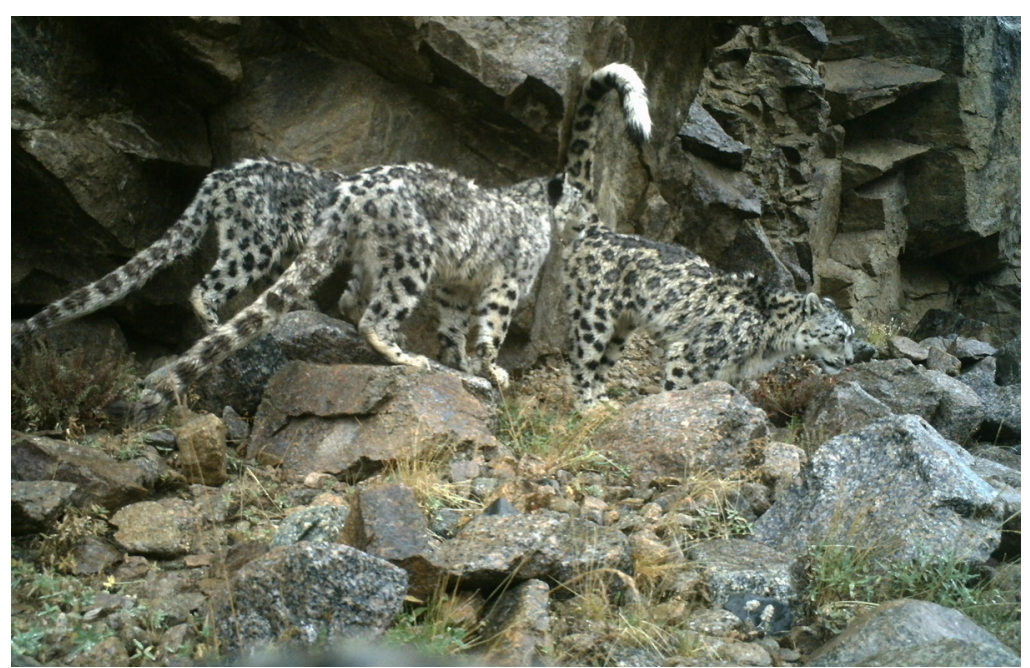

Фото 4. Снежные барсы (самка с подросшими котятами). Снимки с фоторегистраторов в кластере «Шуйский» природного парка «Тыва», 2015 г. Photo 4. A female snow leopard with older cubs. Security camera snapshot at the Shuiskii cluster of Nature Park "Tuva", 2015. спечение долгосрочного сохранения биоразнообразия Алтае-Саянского экорегиона» ключевые очаги обитания снежного барса выявлены на стыке Алтая и Тувы. Ареал ирбиса представлен двумя основными участками - западным и восточным, между которыми имеются промежуточные поселения ирбиса Западного Саяна и Западного Танну-Ола, которые играют ключевую роль в расселении зверей и генетическом обмене между двумя участками ареала. Имеющиеся оценки численности вида основаны на экспертных заключениях и ориентировочно составили по Туве около 40 особей. Однако ситуация с сохранением ирбиса остается нестабильной ввиду возрастающего антропогенного пресса на высокогорные экосистемы, становящиеся 
все более доступными для человека. Основными угрозами для снежного барса в регионе являются: петельный промысел кабарги и волка; облавные охоты с собаками; развитие скотоводства в местах обитания хищника; браконьерский промысел диких животных - объектов питания; а также убийство скотоводами в качестве мести за нападения на скот (Куксин, 2018: 51-52).

Устойчивые группировки снежного барса взяты под охрану на территории заповедника «Убсунурская котловина» и прилегающих к нему заповедников «Алтайский» и «Саяно-Шушенский». Вид успешно размножается на территории кластерного участка «Шуйский» регионального природного парка «Тыва» в Бай-Тайгинском кожууне, об этом свидетельствуют ежегодные данные, получаемые с установленных на особо охраняемой природной территории (ООПТ) фоторегистраторов (фото 4).

В зоологической коллекции музея имеются два чучела снежного барса, изготовленные из заказанных по плану музея шкур таксидермистом И. М. Путинцевым в 1955 г. и В. И. Шмаковым в 1994 г. Они представлены в экспозиции «Высокогорные экосистемы». Состояние чучел удовлетворительное, требуется очистка меха.

\section{Манул (дикий кот) (Felis manul Pallas, 1776).}

Категория и статус: 3 - восстанавливающийся вид.

Манул (по-тувински маны) относится к отряду хищные (Carnivora), семейству кошачьи (Felidae). В музее имеется чучело манула (в двух экземплярах), изготовленное И. М. Путинцевым в 1954 и в 1999 гг., а также шкуры выделки Московской биофабрики. Их состояние удовлетворительное, требуется легкая очистка меха и создание удобного постамента для чучел.

Вид в прошлом был обычным на южных микросклонах Западной и Восточной Танну-Ола, в Центральнотувинской и Хемчикской котловинах, но его ареал не доходил до бассейна Бий-Хема. До 1970-х годов манул добывался по всей республике. С вводом запрета на его добычу, ареал и численность вида начали восстанавливаться, и уже в первой половине 1980-х годов он встречался почти во всех районах республики (Шурыгин, 2002: 140).

В настоящее время состояние численности не вызывает опасения. Манул является единственным видом, популяция которого успешно восстановлена в регионе (фото 5). Наряду с принимаемыми мерами по сохранению манула,

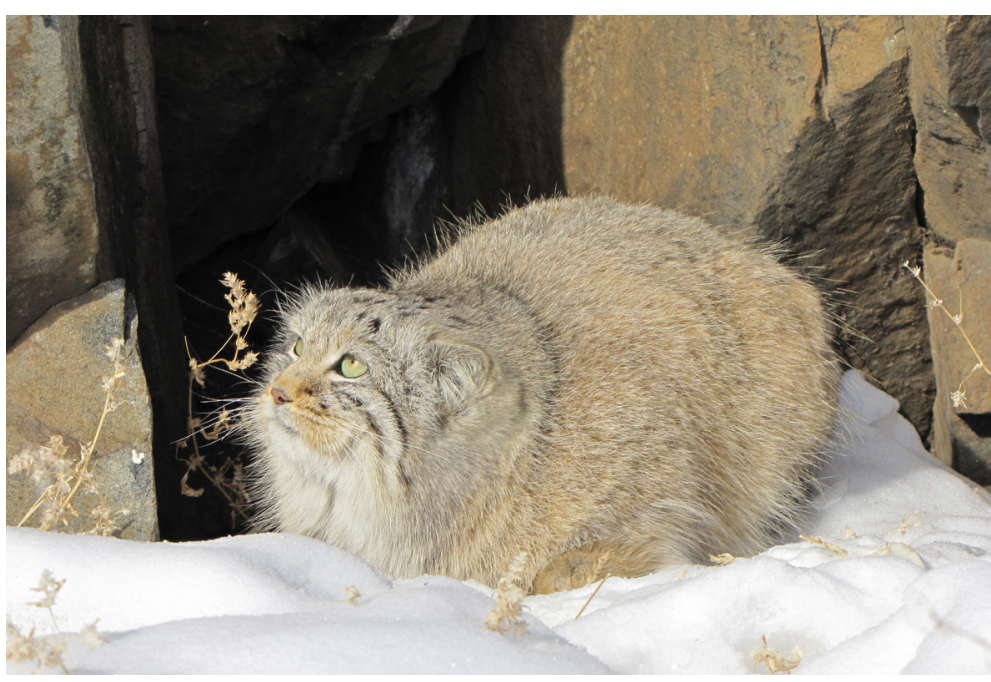

Фото 5. Степной кот манул у своей норы. Фото А. Барашковой, 20112. Photo 5. The Pallas's cat (manul) at its den. Photo by A. Barashkova, 2011. основной причиной такого положительного процесса может быть прекращение распашки степей и связанных с этим массовое истребление грызунов - объектов добычи этого дикого степного кота.

Таким образом, если на примере с дзереном, которого считают утраченным для фауны Тувы, мы видим негативные последствия человеческой деятельности, то восстановление манула, одного из трех видов диких кошек нашей фауны, доказывает возможность регулирования антропогенного фактора. И здесь роль музея как просветительского и, в перспективе, научного центра огромна.

\section{Тувинский бобр (Castor fiber tuvinicus Lavrov, 1969).}

Категория и статус: 1 - находящийся под угрозой исчезновения вид.

Вид с очень ограниченным ареалом, относится к отряду грызунов (Rodentia), семейству бобровых (Castoridae), эндемик Тувы. В зоологической коллекции музея имеется чучело бобра (по-тувински сарыг кундус), изготовленное И. М. Путинцевым в 1954 г., а также шкуры выделки Московской биофабрики.

После создания в 1976 г. в бассейне р. Азас комплексного республиканского заказника, впоследствии (в 1984 г.), преобразованного в государственный заповедник, бобры начали активно расселяться по всему бассейну Азаса - местах былого обитания. Далее, благодаря охранной деятельности запо- 
ведника, наблюдался рост численности бобров, которая в конце 1980-х гг. составила 100 особей, а в середине 1990-х гг. - 130 (Савельев и др., 2016).

Известно, что в 1953 г. в Тоджинскую котловину было выпущено 38 белорусских бобров, однако проведенными впоследствии исследованиями ущерб генофонду азасской популяции от «пришельцев» не выявлен. Данные исследования проводились в рамках комплексной научной программы «Тувинский бобр» под руководством д. б. н. А. П. Савельева в 1995-2005 гг. Также в рамках данной программы выполнены отдельные проекты: «Реакклиматизация тувинского бобра в Тодже» (2000-2004 гг.); «Изучение, сохранение и восстановление редкого вида тувинского бобра на территории Республики Тыва» (2003 г.). В 1997-2002 гг. проведено изучение популяции тувинского бобра с использованием метода живоотлова и мечения специалистами Всероссийского научно-исследовательского института охотничьего хозяйства и звероводства им. проф. Б. М. Житкова Российской Академии сельскохозяйственных наук (г. Киров) при участии профессоров М. Штуббе и А. Штуббе из Германии (г. Халле). В лаборатории Института цитологии и генетики СО РАН (г. Новосибирск) установлен кариотип тувинского бобра и создан его генетический банк данных. Заложена основа мониторинга тувинского бобра на р. Азас. В 2003-2004 гг. выполнено переселение 17 бобров с р. Азас на р. Белин, в результате был создан новый очаг обитания тувинского бобра (Научная программа «Тувинский бобр»: Электр. ресурс). С 2015 г. данная территория охраняется образованным там кластерным участком «Уш-Белдир» природного парка «Тыва».

Тувинские бобры в настоящее время высоко уязвимы воздействию биотических факторов среды и, в первую очередь, антропогенному прессу (браконьерство, рекреация). Кроме того, сегодня важнейшим условием сохранения аборигенной популяции является недопустимость интродукции в пределы ее коренного ареала особей других подвидов бобра, гарантирующая сохранение генетической чистоты тувинского бобра. Такая угроза, по мнению специалистов, уже существует, и сегодня стоит задача регулирования численности неаборигенных видов (Кельбешеков, 2005).

Вид экспонируется в музее в разделе «Сезонные изменения в природе». В связи с возрастанием проникновения людей в местообитания тувинского бобра, работу по популяризации сохранения эндемика Тувы в музее необходимо продолжать.

\section{Серый (алтайский) сурок (Marmota baibacina Kastschenko, 1889).}

Категория и статус: 2 - сокращающийся в численности вид.

Редкий и исчезающий вид в Туве. В Монгун-Тайгинском районе его численность низкая. Был распространен по восточному макросклону хр. Чихачёва, окрестностях оз. Хиндиктиг-Холь и в верхней части бассейна р. Моген-Бурен. Относительно высокие показатели численности регистрировались только в верхней части долины Асхатийн-Гол на границе с Монголией. На остальной территории преобладают очажковые поселения сурков с низкой численностью, часто временные (Шурыгин, Ондар, 2018: 34).

Наряду с тарбаганом (монгольским сурком), также редким видом, сурок является важным ресурсом высокогорной фауны как объект добычи снежного барса, других хищников. Несмотря на «краснокнижный» статус, сурки массово добываются местными жителями. Хотя раньше мех использовался на изготовление головных уборов, сегодня данная традиция почти изжита. Мясо сурков считается целебным, а жир используется в народной медицине.

Виды сурков представлены в экспозиции «Высокогорные экосистемы».

\section{Заключение}

Учет таксидермического материала млекопитающих, относящихся к редким и исчезающим видам фауны и их предварительная инвентаризация показали, что «краснокнижные» виды зоологической коллекции животных Национального музея Тувы находятся в удовлетворительном состоянии, а также по статусу относятся: 6 видов - к 1 категории редкости, 1 вид - к 2 категории, 12 видов - к 3 категории, по одному виду к 4 и 5 категории.

\footnotetext{
${ }^{1}$ Кариоти́п - совокупность признаков хромосомного набора, характерная для каждого биологического вида. $\mathrm{K}$ таким признакам относятся число, размер, форма хромосом и детали их микроскопического строения. Кариотип служит «паспортом» вида, надежно отличающим его от кариотипов других видов (Биология. Современная иллюстрированная энциклопедия, 2006: 184).
} 
НОВЫЕ ИССЛЕДОВАНИЯ ТУВЫ

www.nit.tuva.asia

Наличие экспонатов, представленных объектами животного мира, в том числе, редкими и исчезающими видами Алтае-Саянского экорегиона, позволяет краеведческому отделу музея проводить большую эколого-просветительскую и воспитательную работу среди широких слоев населения. В этой связи, кроме хранительских и просветительских работ, на основании данных по редким животным, имеющимся в фондах музея, можно начать проведение работ научно-исследовательского уровня: по их систематике, численности и распределению на территории республики.

Проблема в изучении редких и исчезающих животных, их местообитаний, а также их депопуляции состоит в том, что в настоящий момент полноценных исследований в данном направлении в республике не проводится. Для ведения региональной Красной книги необходимо проводить мониторинговые исследования согласно соответствующим требованиям. Действительность такова, что подготовка и издание Красной книги происходит за критически малый срок, приводя к многочисленным неточностям.

Несмотря на то, что функции по мониторингу редких и исчезающих объектов животного и растительного мира возложены на региональное министерство природных ресурсов и экологии, в структуре данного органа исполнительной власти научного отдела не имеется. Государственные инспекторы по охране объектов животного мира проводят ежегодные учеты численности животных, однако специальных исследований по «краснокнижным» животным они не осуществляют. В двух заповедниках Тувы федерального значения («Убсунурская котловина» и «Азас»), имеющих научные отделы, исследования по редким животным и растениям проводятся в основном в пределах границ данных особо охраняемых природных территорий (ООПТ). Относительный мониторинг численности архара и снежного барса в заповедниках проводится совместно с другими ООПТ Алтае-Саянского экорегиона и финансово поддерживаются грантами различных природоохранных фондов и крупных компаний.

В связи с вышеизложенным, предлагается обозначить одним из направлений научной деятельности музея проведение исследований по редким и исчезающим видам флоры и фауны. Эту работу можно проводить, опираясь на сотрудничество с исследователями академических институтов и вузов региона. Бесспорным фактом является наличие фондового материала, хранящегося в соответствующих условиях, что может позволить музею выступать в роли базового научного учреждения. Также данные исследования позволят пополнить единицами или обновлениями сведений не только часть коллекции по «краснокнижной» фауне, но и естественнонаучный фонд в целом.

Поскольку музей является социальным институтом, необходимы также социологические исследования, позволяющие определить степень восприятия посетителями редких и исчезающих видов как музейный предмет. Такой мониторинг можно также сочетать с исследовательской работой по редким видам флоры и фауны с привлечением школьных музеев. Сегодня получение информации от населения возможно с помощью мобильной связи или через социальные сети, например, о встречах с животными или о фактах их добычи, о численности и местах обнаружения.

\section{СПИСОК ЛИТЕРАТУРЫ}

Биология. Современная иллюстрированная энциклопедия (2006) / гл. ред. А. П. Горкин. М.: Росмэн-Пресс. 560 с.

Дыртык-оол, А. О. (2005) Национальный музей имени Алдан-Маадыр Республики Тыва: история и современность // Музей в XXI веке: проблемы и перспективы / сост. А. О. Дыртык-оол. Кызыл: КЦО «Аныяк». 160 с. С. $34-37$.

Ильяшенко, В. Ю., Ильяшенко, Е. И. (2000) Красная книга России: правовые аспекты. М. : б. и. 143 с.

Кельбешеков, Б. К. (2005) Проблемы сохранения тувинского подвида бобра // Труды заповедника «Тигирекский». № 1. С. 297-299.

Кирилюк, В. Е., Лущекина, А. А. (2017) Современное состояние дзерена (Procapra gutturosa: Bovidae) в России // Nature Conservation Research. Заповедная наука. T. 2 (Suppl. 1). C. 81-99. DOI: 10.24189/ncr.2017.018

Конвенция о международной торговле видами дикой фауны и флоры, находящимися под угрозой исчезновения. Принята 3 марта 1973 года [Электронный ресурс] // ООН. Конвенции и соглашения. URL: https://www.un.org/ ru/documents/decl_conv/conventions/cites.shtml (дата обращения: 20.02.2019).

Красная книга Республики Тыва: Животные (2002) / науч. ред. Н. И. Путинцев, Л. К. Аракчаа, В. И. Забелин, В. В. Заика. Новосибирск : Изд-во СО РАН. 168 с.

Красная книга Республики Тыва: Растения (2002) / отв. ред. И. М. Красноборов. Новосибирск : Изд-во СО РАН. 150 c.

Красная книга Республики Тыва (животные, растения и грибы) (2018). 2-е изд. перераб. / отв. ред. С. О. Ондар, Д. Н. Шауло. Кызыл : Фаворит. 564 с. 
Красная книга СССР. Редкие и находящиеся под угрозой исчезновения виды животных и растений (1978) / ред. А. М. Бородин, А. Г. Банников, Е. Е. Сыроечковскийи др. М. : Изд-во «Лесная промышленность». 460 с.

Куксин, А. Н. (2018) Ирбис (снежный барс) // Красная книга Республики Тыва (животные, растения и грибы). 2-е изд. перераб. / отв. ред. С. О. Ондар, Д. Н. Шауло. Кызыл : Фаворит. 564 с. С. 51-52.

Научная программа «Тувинский бобр» [Электронный ресурс] // Особо охраняемые природные территории Российской Федерации. URL: http://zapoved.ru/science/topic/403/Научная-программа-ТУВИНСКИЙ-БОБР (дата обращения 19.02.2019).

Савельев, А. П., Карташов, Н. Д., Путинцев, Н. И., Штуббе, М., Штуббе, А., Молокова, Н. И., Демкин, И. В. (2016) Программа «Тувинский бобр»: основные результаты 20-летней работы // Современное состояние редких видов растений и животных Республики Тыва. Материалы Всероссийской научно-практической конференции (28-29 апреля 2016 г.) / отв. ред. У. В. Ондар. Кызыл: Изд-во ТувГУ. 130 с. С. 106-116.

Смирнов, М. Н. (2002а) Дзерен // Красная Книга Республики Тыва: животные / науч. ред. Н. И. Путинцев, Л. К. Аракчаа, В. И. Забелин, В. В. Заика. Новосибирск : Изд-во СО РАН. 168 с. С. 144-145.

Смирнов, М. Н. (2002b) Лесной северный олень // Красная Книга Республики Тыва: животные / науч. ред. Н. И. Путинцев, Л. К. Аракчаа, В. И. Забелин, В. В. Заика. Новосибирск : Изд-во СО РАН. 168 с. С. 143-144. 102 c.

Сорокин, П. А. (2005) Филогеография монгольского дзерена (Procapra gutturosa): дисс. ... канд. биол. наук. М.

Титлянова, А. А., Миронычева-Токарева, Н. П., Романова, И. П., Косых, Н. П., Кыргыс, Ч. С., Самбуу, А. Д. (2002) Продуктивность степей // Степи Центральной Азии / отв. ред. И. М. Гаджиев, А. Ю. Королюк, А. А. Титлянова и др. Новосибирск : Изд-во СО РАН. 229 с. С. 95-173.

Шурыгин, В. В. (2002) Манул // Красная Книга Республики Тыва: животные / науч. ред. Н. И. Путинцев, Л. К. Аракчаа, В. И. Забелин, В. В. Заика. Новосибирск : Изд-во СО РАН. 168 с. С. 140-141.

Шурыгин, В. В., Ондар, С. О. (2018) Серый (алтайский) сурок // Красная книга Республики Тыва (животные, растения и грибы). 2-е изд. перераб. / отв. ред. С. О. Ондар, Д. Н. Шауло. Кызыл : Фаворит. 564 с. С. 34-35.

Donahoe, B. (2004) A Line in the Sayans: History and Divergent Perceptions of Property Among the Tozhu and Tofa of South Siberia. Unpublished Ph.D. dissertation, Indiana University, Department of Anthropology. 329 p.

Дата поступления: 01.03.2019 2.

\section{REFERENCES}

Biologiia. Sovremennaia illiustrirovannaia entsiklopediia [Biology. A modern illustrated encyclopedia] (2006) / ed. by A. P. Gorkin. Moscow, Rosmen-Press. 560 p. (In Russ.).

Dyrtyk-ool, A. O. (2005) Natsional'nyi muzei imeni Aldan-Maadyr Respubliki Tyva: istoriia i sovremennost' [The Aldan-Maadyr National Museum of the Republic of Tuva: past and present]. In: Muzei $v$ XXI veke: problemy i perspektivy [The museum in the 21st century: issues and prospects] / comp. by A. O. Dyrtyk-ool. Kyzyl, KTsO «Anyiak». 160 p. Pp. 34-37. (In Russ.).

Il'iashenko, V. Iu. and Il'iashenko, E. I. (2000) Krasnaia kniga Rossii: pravovye aspekty [The Red Data Book of Russia: legal aspects]. Moscow, s. n. 143 p. (In Russ.).

Kel'beshekov, B. K. (2005) Problemy sokhraneniia tuvinskogo podvida bobra [The problems of protecting the Tuvan beaver subspecies]. Trudy zapovednika «Tigerekskii», no. 1, pp. 297-299. (In Russ.).

Kiriliuk, V. E. and Lushchekina, A. A. (2017) Sovremennoe sostoianie dzerena (Procapra gutturosa: Bovidae) v Rossii [The current state of the dzeren (Procapra gutturosa: Bovidae) in Russia]. Nature Conservation Research. Zapovednaia nauka, vol. 2 (Suppl. 1), pp. 81-99. DOI: 10.24189/ncr.2017.018 (In Russ.).

Konventsiia o mezhdunarodnoi torgovle vidami dikoi fauny i flory, nakhodiashchimisia pod ugrozoi ischeznoveniia. Priniata 3 marta 1973 goda [Convention on International Trade in Endangered Species of Wild Fauna and Flora. Adopted on 3 March 1973]. OON. Konventsii i soglasheniia [online] Available at: https://www.un.org/ru/documents/decl_conv/ conventions/cites.shtml (access date: 20.02.2019). (In Russ.).

Krasnaia kniga Respubliki Tyva: Zhivotnye [The Red Data Book of the Republic of Tuva: Animals] (2002) / ed. by N. I. Putintsev, L. K. Arakchaa, V. I. Zabelin and V. V. Zaika. Novosibirsk, SO RAN Publ. 168 p. (In Russ.).

Krasnaia kniga Respubliki Tyva: Rasteniia [The Red Data Book of the Republic of Tuva: Plants] (2002) / ed. by I. M. Krasnoborov. Novosibirsk, SO RAN Publ. 150 p. (In Russ.).

Krasnaia kniga Respubliki Tyva (zhivotnye, rasteniia i griby) [The Red Data Book of the Republic of Tuva: animals, plants and mushrooms] (2018). $2^{\text {nd }}$ ed. / ed. by S. O. Ondar and D. N. Shaulo. Kyzyl, Favorit. 564 p. (In Russ.).

Krasnaia kniga SSSR. Redkie i nakhodiashchiesia pod ugrozoi ischeznoveniia vidy zhivotnykh i rastenii [The Red Data Book of the USSR: Rare and endangered species of animals and plants] (1978) / ed. by A. M. Borodin, A. G. Bannikov, E. E. Syroechkovskii et al. Moscow, Lesnaia promyshlennost' Publ. 460 p. (In Russ.). 
НОВЫЕ ИССЛЕДОВАНИЯ ТУВЫ

www.nit.tuva.asia

Kuksin, A. N. (2018) Irbis (snezhnyi bars) [The irbis (snow leopard)]. In: Krasnaia kniga Respubliki Tyva (zhivotnye, rasteniia i griby) [The Red Data Book of the Republic of Tuva: animals, plants and mushrooms] (2018). $2^{\text {nd }}$ ed. / ed. by S. O. Ondar and D. N. Shaulo. Kyzyl, Favorit. 564 p. Pp. 51-52. (In Russ.).

Nauchnaia programma «Tuvinskii bobr» [The "Tuvan beaver" research program]. Osobo okhraniaemye prirodnye territorii Rossiiskoi Federatsii [online] Available at: http://zapoved.ru/science/topic/403/Nauchnaia-programma-TUVINSKII-BOBR (access date 19.02.2019). (In Russ.).

Savel'ev, A. P., Kartashov, N. D., Putintsev, N. I., Shtubbe, M., Shtubbe, A., Molokova, N. I. and Demkin, I. V. (2016) Programma «Tuvinskii bobr»: osnovnye rezul'taty 20-letnei raboty [The "Tuvan beaver": the main results of 20 years of work]. In: Sovremennoe sostoianie redkikh vidov rastenii i zhivotnykh Respubliki Tyva [The current state of rare species of plants and animals in the Republic of Tuva]. Proceedings of the all-Russian conference (28-29 April 2016). / ed. by U. V. Ondar. Kyzyl, TuvGU Publ. 130 p. Pp. 106-116. (In Russ.).

Smirnov, M. N. (2002a) Dzeren [The Mongolian gazelle]. In: Krasnaia kniga Respubliki Tyva: Zhivotnye [The Red Data Book of the Republic of Tuva: Animals] (2002) / ed. by N. I. Putintsev, L. K. Arakchaa, V. I. Zabelin and V. V. Zaika. Novosibirsk, SO RAN Publ. 168 p. Pp. 144-145. (In Russ.).

Smirnov, M. N. (2002b) Lesnoi severnyi olen' [The forest reindeer]. In: Krasnaia kniga Respubliki Tyva: Zhivotnye [The Red Data Book of the Republic of Tuva: Animals] (2002) / ed. by N. I. Putintsev, L. K. Arakchaa, V. I. Zabelin and V. V. Zaika. Novosibirsk, SO RAN Publ. 168 p. Pp. 143-144. (In Russ.).

Sorokin, P. A. (2005) Filogeografia mongol'skogo dzerena (Procapra gutturosa) [Phylogeography of the Mongolian gazelle (Procapra gutturosa)]: Diss.... Candidate of Biology. Moscow. 102 p. (In Russ.).

Titlianova, A. A., Mironycheva-Tokareva, N. P., Romanova, I. P., Kosykh, N. P., Kyrgys, Ch. S. and Sambuu, A. D. (2002) Produktivnost' stepei [Productivity of steppes]. In: Stepi Tsentral'noi Azii [Steppes of Central Asia] / ed. by I. M. Gadzhiev, A. Iu. Koroliuk, A. A. Titlianova et al. Novosibirsk, SO RAN Publ. 229 p. Pp. 95-173. (In Russ.).

Shurygin, V. V. (2002) Manul. [The Pallas’s cat]. In: Krasnaia kniga Respubliki Tyva: Zhivotnye [The Red Data Book of the Republic of Tuva: Animals] (2002) / ed. by N. I. Putintsev, L. K. Arakchaa, V. I. Zabelin and V. V. Zaika. Novosibirsk, SO RAN Publ. 168 p. Pp. 140-141. (In Russ.).

Shurygin, V. V. and Ondar, S. O. (2018) Seryi (altaiskii) surok [The grey (Altai) groundhog]. In: Krasnaia kniga Respubliki Tyva (zhivotnye, rasteniia i griby) [The Red Data Book of the Republic of Tuva: animals, plants and mushrooms] (2018). $2^{\text {nd }} \mathrm{ed}$. / ed. by S. O. Ondar and D. N. Shaulo. Kyzyl, Favorit. 564 p. Pp. 34-35. (In Russ.).

Donahoe, B. (2004) A Line in the Sayans: History and Divergent Perceptions of Property Among the Tozhu and Tofa of South Siberia. Unpublished Ph.D. dissertation, Indiana University, Department of Anthropology. 329 p.

Submission date: 01.03.2019. 